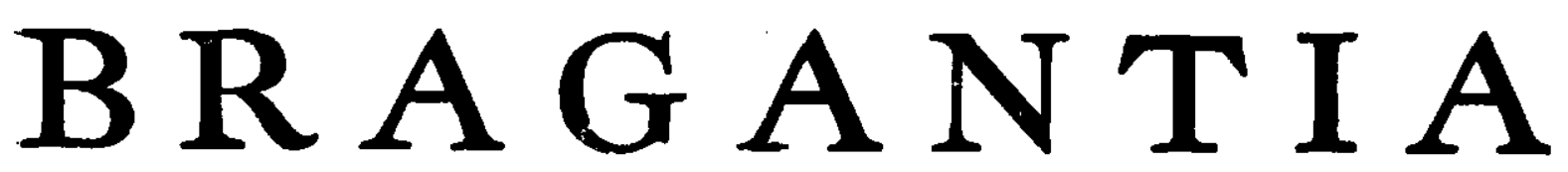

Boletim Técnico da Divisão de Experimentação e Pesquisas I N S T I T U T O A G R O Nô M I CO

Vol. 6 Campinas, Maio de 1946 N. 5

\title{
A FUNÇ̃̃O E A ESTRUTURA DOS PLASTÍDIOS DAS CÉLULAS PARENQUIMATOSAS QUE ENVOLVEM OS FEIXES VASCULARES DA FÔLHA DO MILHO $\left.{ }^{*}\right)$
}

\author{
M. M. Rhoades (**) \\ Alcides Carvalho ${ }^{* * * *}$ )
}

Fim conexão com um estudo genético da variegação de clorofila no milho (8), tivemus oportunidade de preparar, para estudos citológicos, numercsas lâminas contendo cortes transversais e longitudinais de fôlhas desta gramínea. Examinando o material em aprêço, chamou a nossa atenção a ocorrência de uma espécie de plastídio, de formato bem diferente, na camada única de células parenquimatosas que envolve os feixes vasculares (células do invólucro do feixe vascular). Ao rever a literatura sôbre o assunto, não encontramos nenhuma descrição dêsses plastídios que, realmente, estivesse de acôrdo com a nossa concepção sôbre sua estrutura e função. Por êste motivo, apresentaremos, a seguir, uma breve descrição dos mesmos.

Muitas gramíneas possuem duas camadas de células envolvendo os feixes vasculares, enquanto outras possuem apenas uma única. Schwendener (10) deu o nome de invólucro parenquimatoso à camada externa, e o de mestoma à camada interna, cujas células apresentam as paredes mais internas frequentemente reforçadas. As células do invólucro parenquimatoso de algumas gramíneas possuem cloroplastos, enquanto as de outras gramíncas são completamente desprovidas de côr. Os membros da subfamília Pooideæ, por exemplo, apresentam os feixes vasculares envolvidos por um mestoma de paredes espêssas e circundado por um invólucro parenquimatoso, ao passo que os representantes da subfamília Panicoideæ os apresentam apenas circundados pelo invólucro parenquimatoso (1). Já foi determinado, há algum tempo, que as células dêsse invólucro parenqui-

(*) Trad. do Bulletin of The Torrey Botanical Club 71, 335-46, 1944.

(**) Professor de Genética da "Columbia University" de Nova Iorque.

(**) Estudo realizado durante a estadia na "Columbia University", com uma bolsa de estudos da Fundaçāo Rockefeller. 
matoso, em muitas gramíneas, encerram cloroplastos e a sua ocorrência levou Haberlandt (5) a sugerir que talvez essas células verdes do invólucro pudessem ter uma função ainda desconhecida, além da que thes é normal, isto é, a de um tecido condutor e a de um auxiliar, de pouca importância, é verdade, ao aparelho clorofílico da planta. Embora essa questão proposta por Haberlandt tenha já, em parte, sido resolvida, é objeto do presente artigo a apresentação de outros estudos sôbre a estrutura e função dos cloroplastos das células do invólucro parenquimatoso que envolvem os feixes vasculares da fôlha do milho.

Schwendener (10) e Strasburger (13) relataram que êsse invólucro, no milho, apresentava clorofila. Kiesselbach (6) observou que as suas células continham cloroplastos maiores do que os do mesófilo e, posteriormente, estabeleceu que êstes plastídios "tomavam uma forma alongada anormal e permaneciam recurvados e agrupados mais do lado externo das células", quando submetidos à ação de um agente fixador cromo-acético. Weatherwax (14) menciona também os grandes e proeminentes cloroplastos do invólucro parenquimatoso, mas nada acrescenta de novo às observações de Kiesselbach. Eames e MacDanicls (3) apresentam uma secção transversal de uma fôlha de milho que dá uma idéia errônea dos plastídios do invólucro parenquimatoso. Estes autores dão ainda o nome de mestoma ao invólucro parenquimatoso das gramíneas, o que está em desacôrdo com a terminologia de outros investigadores. Avery (2) representa e descreve, ligeiramente, o invólucro parenquimatoso dos feixes vasculares da fôlha do milho, estabelecendo o seguinte: "Os feixes são circundados por um invólucro que possui clorofila. Os cloroplastos de suas células diferem dos outros cloroplastos da fôlha". Arber (1) apresenta uma secção transversal de um feixe vascular de uma fôlha de milho, mostrando o invólucro parenquimatoso, porém não faz referência aos seus plastídios. Sharman (11) e Esau (4) realizaram cuidadosos estudos sôbre a ontogenia dos feixes vasculares do milho. Esau notou que as células do invólucro continham cloroplastos abundantes e grandes, enquanto Sharman nem menciona os plastídios. As publicações acima citadas apenas concordam no que diz respeito ao invólucro parenquimatoso, isto é, que a camada única de células, que forma êsse invólucro na fôlha do milho, encerra numerosos cloroplastos, maiores que os cloroplastos das vélulas do mesófilo.

Zirkle (17), em um estudo intensivo dos plastídios do milho, reconheceu que as células do invólucro do feixe vascular continham cloroplastos especializados, que se relacionavam com o armazenamento do amido. Em sua opinião, quando as condições do meio cram favoráveis à fotossíntese, os plastídios menores do mesófilo apresentavam vacúolos centrais, contendo amido. Supunha ainda êsse autor que cada plastídio das células do invólucro do feixe vascular contivesse um grão de amido localizado no centro do vacúolo. Ainda de acôrdo com Zirkle, a superfície dêstes plastídios apresentava poros que se comunicavam com o vacúolo central. Quando os plastídios se achavam orientados com a superfície plana paralela ao campo de visão, os poros apareciam circulares; porém, quando vistos de lado, os poros se apresentavam com a forma de fendas muito estreitas. Con- 
cluiu, assim, dessas observações, que os poros estavam concentrados nas superfícies mais planas do plastídio e se comunicavam com o vacúolo sem, todavia, se orientar para o centro do plastídio. Julgamos que Zirkle não interpretou, satisfatòriamente, várias estruturas importantes. Mais adiante discutiremos ainda outras interpretaçöes de Zirkle sôbre êstes mesmos plastídios.

Weier (15), em um artigo sôbre a possível homologia entre os plastídios e o corpo de Golgi, apresenta uma célula de uma fôlha de milho que, sem dúvida, pertence ao invólucro parenquimatoso, embora assim não o estabeleça. Achou êsse autor que os plastídios desta célula continham "cavidades" cheias de amido, mas não se refere, entretanto, à espécie de cloroplastos que se encontram nas células do mesófilo e do invólucro dos feixes vasculares.

\section{A ESTRUTURA DO PLASTÍDIO DO INVOLUUCRO DO FEIXE VASCULAR}

Uma rápida revisão da enorme literatura, cheia de controvérsias, revela que a aparente estrutura dos plastídios, após a fixação, pode diferir bastante da encontrada nas células vivas. Considerando que a maioria das nossas observações foi feita em material fixado, pode-se concluir que os nossos comentários sôbre a estrutura dêsses plastídios não devem ser tomados como definitivos até que um estudo mais detalhado seja efetuado. Entretanto, como já não existem mais dúvidas sôbre alguns de seus caraterísticos mais evidentes, resolvemos, a seguir, descreve-los em detalhes.

Kiesselbach (6) verificou, no milho, uma notável diferença entre a aparência dos plastídios fixados, do invólucro dos feixes vasculares, e a dos plastídios vivos dêsses mesmos feixes. Acredita êsse autor que o fixador faz com que os plastídios tomem uma orientação recurvada anormal dentro das células. As nossas observações indicam, entretanto, que é duvidosa a ocorrência de qualquer movimento, exceto para as mudanças de posição, devidas a alterações no tamanho e na forma dos plastídios durante a fixação. Em cortes de fôlhas frescas de milho, à mão livre, montadas em água, os plastídios absorvem água e se distendem. As figuras obtidas dêsses plastídios são semelhantes, quer usando os fixadores de Regaud, de Champy ou os de Craf. A sua aparência, após a fixação, se assemelha à do material vivo, montado em óleo de parafina.

Em material fixado e colorido com a hematoxilina, os plastídios se assemelham a elipsóides achatados com uma borda fortemente colorida, envolvendo, parcialmente, uma região central que se colore menos intensamente (Figs. 1, 3, 6 e 8). Quando vistos em posições diferentes, êsses plastídios apresentam variadas formas, devido à sua própria forma assimétrica.

Os plastídios do invólucro dos feixes, especialmente os que não possuem grãos de amido, quando vistos de frente, mostram uma notável semelhança aos dictiosomas do aparelho de Golgi. Em plastídios sem amido, a borda 
mais fortemente colorida parece conter numerosas áreas pequenas, incolores, que se assemelham a vacúolos. E nestas regiões do plastídio, semelhantes a vacúolos, que o amido é, mais tarde, depositado. Os "vacúolos" e os grãos de amido têm a inesma forma e aproximadamente o mesmo tamanho. Quando os grãos de amido estão presentes êles se acham embutidos no plastídio, fazendo, entretanto, saliência na superfície do plastídio. A região contral do plastídio não contém vacúolos para amido e nem grãos de amido. O número de "vacúolos" formadores de amido em um plastídio, isento de amido, pode ser igual ao número de grãos de amido subsequentemente formados por êsse mesmo plastídio. E possível, porém, que logo que um dêstes: "vacúolos" tenha formado um grão de amido maduro comece a elaboração de um segundo e assim por diante, de modo que o número de grãos de amido formado pode ser maior do que o número de regiões formadoras de amido. Uma resposta decisiva a êste problema podia ser dada ou por uma acurada determinação do número de "vacúolos" $\mathrm{em}$ um plastídio vivo e o número de grâos de amido achado mais tarde, ou por um estudo estatístico do material fixado. Em um só plastídio, os grãos de amido, que estão dispostos em diversas camadas quando vistos pelos bordos, variam $\mathrm{cm}$ número de pouco mais do que 20 até mais do que 40 . Os grãos de amido individuais Não fàcilmente destacados da superfície do plastídio e podem se encontrar flutuando livremente no líquido de montagem da lâmina. Fistes grãos destacados são especialmente visíveis em preparações coloridas com iodo, onde aparecem como corpos elipsoidais coloridos de azul. Embora um plastíclio contenha um certo número de grãos de amido, cada grão de amido é. normalmente, simples e não composto. A fig. 2 representa uma seç̧ão de um plastídio novo contendo 20 grãos de amido individuais. Dez dêsses grãos permaneceram em um só plano; o restante acima e abaixo dêsse plano. Fstas regiões definidas, isto é, os vacúolos do plastídio do invólucro parenquimatoso, relacionadas com a formação de amido, são semelhantes em função, embora não o sejam em estrutura, aos perinóides dos plastídios das algas e musgos.

Uma situação comparável a esta foi referida por Zirkle (16) para o plastídio comum (do mesófilo) de Elodea canadensis, que possui um vacúolo central contendo um único grão de amido. Êste vacúolo é visível, quando não há amido.

As células do invólucro parenquimatoso que envolve os feixes vasculares novos do milho têm plastídios menores do que as células mais velhas. Cistes plastídios não só encerram menor número de grãos de amido como também são menos achatados do que os plastídios dos feixes maduros.

A descrição, acima apresentada, dos plastídios do invólucro parenquimatoso difere em diversos pontos fundamentais da descrição dada por Zirkle (17). O que êste autor julga serem poros do plastídio que se dirigem ao vacúolo localizado no centro, são, na verdade, grãos de amido que não se colorem com a hematoxilina e que, assim, aparecem incolores (17) (Fig. 1). Crê ainda Zirkle que cada plastídio contém um grão de amido único e centralmente localizado. Como já notamos, porém, êstes plastídios podem ter até 40 grãos de amido. Zirkle relatou ainda que os plastídios do mesófilo continham amido em seus vacúolos centrais, quando as condị̧ões 
se apresentavam especialmente favoráveis à fotossíntese. Em nossas experiências com milho cultivado ao ar livre, não achamos nem traços de amido nestes plastídios, quer usando o teste de iodo ou a luz polarizada. Observamos o mesmo quando grande quantidade de amido se achava nos plastídios do invólucro dos feixes vasculares (Figs. 4-5). Concluimos que a síntese do amido normalmente não ocorre nos plastídios do mesófilo. Estes são relacionados com a elaboração dos carbohidratos solúveis. Pudemos verificar, pela observação da notável transformação dos plastídios do mesófilo em plastídios semelhantes aos do invólucro, que as diferenças em estrutura e função entre os plastídios do mesófilo e do invólucro podem ser apenas um reflexo das condições fisiológieas locais, especialmente da concentração de açúcares solúveis, quando a quantidade de açúcar presente na fôlha é bastante aumentada, e não devidas a diferenças intrílisecas. Isso observamos quando imergimos a extremidade de um pedaço de fôlha. nova de milho em uma solução concentrada de sacarose ( $27 \mathrm{gr}$ de sacarose por 100 ec de água). Depois de 30 horas nesta solução, os plastídios do mesófilo, na porção da fôlha justamente acima do nível da solução, continham, cada um, alguns grãos de amido simples. Setenta e oito horas depois da imersão na solução de açúcar, a mudança dos plastídios do mesófilo em plastídios semelhantes aos do invóluero já era pràticamente completa. Excetuando o fato de que os plastídios do mesófilo, que são menores, continham um menor número de grãos de amido, porém de dimensões maiores, êles pareciam-se hastante com os plastídios do invólucro. Fim fôlhas de desenvolvimento normal, os açúcares elaborados nas células do mesófilo movem-se para as células do invólucro do fcixe vascular. Provàvelmente, a concentração de açúcar nas células do mesófilo permanece em um nível relativamente baixo, enquanto a concentração do açúcar do involucro do feixe vascular se torna cada vez maior. Sob tais condições, os plastídios do mesófilo têm a ver apenas com a atividade fotossintética, enquanto os plastídios do invólucro elaboram $\mathrm{c}$, temporàriamente, armazenam $\mathrm{o}$ amido. Entretanto, se a concentração de açúcar das células do mesófilo se torna anormalmente alta, poder-se-á esperar, conforme a experiência acima, que os plastídios do mesófilo também contenham amido.

De há muito se sabe que os plastídios contidos nas células do invólucro dos feixes vasculares da fôlha do milho são de côr verde, embora seja essa coloração mais clara que a dos plastídios do mesófilo. Se êsse pigmento fôsse a clorofila então êsses plastídios scriam capazes de efetuar a fotossíntese. $O$ amido dentro dêle depositado podia, neste caso, ser derivado de açúcares aí sintetizados e não de carbohidratos solúveis provenientes das células circundantes do mesófilo. $O$ considerável depósito de amido achado nos plastídios do invólucro nos pareceu ser bem maior do que o esperado de sua própria atividade fotossintética. Realmente, porém, nada sabemos quanto à sua capacidade nesse sentido. No decorrer de nossas investigações, fomos, felizmente, capazes de demonstrar, sem nenhuma dúvida, que o amido encontrado nestes plastídios era realmente derivado dos carbohidratos solúveis, elaborados nos plastídios do mesófilo, e depois translocados para as células do invólucro parenquimatoso, onde então ocorria a síntese dêsse amido. Vejamos como pudemos isso demonstrar. 
Algumas das fôlhas de milho coletadas para o nosso estudo possuiam listas verdes e brancas. Os plastídios nas regiões brancas se apresentavam bem distintos dos plastídios normais, encontrados nas partes verdes da fôlha (8). Na região de transição entre as partes verde e branca de uma dessas fôlhas encontramos um feixe vascular envolvido por células do invólucro parenquimatoso, contendo plastídios perfeitamente normais. De um lado do feixe vascular se encontrava, adjacente a essas células normais do involucro, um conjunto de células do mesófilo, contendo plastídios verdes normais, enquanto, ao lado das células restantes do invólucro, se achavam células do mesófilo, contendo plastídios anormais, isto é, plastídios sem clorofila e, portanto, incapazes de efetuar a fotossíntese. Os plastídios das células do invólucro parenquimatoso que se achavam encostados às células verdes do misófilo se apresentavam cheios de grãos de amido, enquanto os plasth́dios normais das outras células do invólucro parenquimatoso, adjacentes às células do mesófilo, desprovidas de côr, não continham nenhum amido visível. Naturalmente, não se pode concluir, dessa observação, se ocorre ou não alguma fotossíntese nos plastídios verdes do invólucro dos feixess vasculares. Uma certa quantidade de açúcar pode ser elaborada, mas, sendo baixa a sua concentração, pode ser imediatamente removida para dentro dos feixes vasculares.

Tem-se admitido, tàcitamente, que a côr verde-clara dos plastídios do invólucro é a da clorofila. Zirkle (16) notou a côr mais clara dos plastídios do invólucro em Elodea e sugeriu que os mesmos continham tanta clorofila quanto os plastídios menores do mesófilo. Nos plastídios maiores do invólucro, entretanto, a clorofila se achava espalhada em uma camada bem mais fina. Não se pode dizer ao certo se o pigmento verde dos plastídios do invólucro corresponde ou não à mesma clorofila presente nos plastídios do mesófilo. Como se sabe, já se tem demonstrado que há ampla variação nos pigmentos clorofílicos em todo o reino vegetal. Assim é que, por exemplo, Spoehr et al (12) mostraram que certas algas são desprovidas de clorofila $\mathbf{b}$, apresentando, entretanto, a clorofucina. Também não se pode, sumàriamente, desprezar a possibilidade de que, mesmo dentro de uma planta individual, possa haver variação, nas diferentes células, na espécie de clorofila ou na relação da clorofila a para a clorofila $\mathbf{b}$. Sayre (9) achou que as células guardas de Rumex patientia continham um pigmento verde que julgou, na base dos testes microquímicos efetuados, não se tratar da verdadeira clorofila. Desde que o plastídio do invólucro do feixe vascular do milho difere do plastídio do mesófilo em estrutura e função, também a natureza dos seus pigmentos verdes bem pode deixar de ser idêntica.

\section{CICLO DIURNO DA FORMAÇÃO DO AMIDO PELOS PLASTÍdIOS DO INVOLUCRO DOS FEIXES VASCULARES}

Já apresentamos, no capítulo anterior, o motivo que nos levou a concluir que o amido depositado nos plastídios do invólucro do feixe vascular é proveniente de carbohidratos solúveis elaborados nas células do mesófilo 
e transferidos para as células do invóluero, onde ocorre a sua transformação em amido. Discutiremos, a seguir, as experiências que indicaram que a transformação de carbohidratos solúveis em amido ocorre nos plastídios do invólucro do feixe vascular apenas quando a velocidade da transferência do açúcar das células do mesófilo para o interior das células do invólucro é maior do que a velocidade da translocação dêsses carbohidratos das células do invólucro do feixe para o interior dos elementos dos feixes vasculares. Indicaremos, além disso, que o amido que se acumula em quantidades crescentes durante o dia, nestes plastídios, é de novo transformado em carbohidratos solúveis, durante a noite, quando não há atividade fotossintética, de modo que, pela manhã, os plastídios do invólucro do feixe vascular se apresentam desprovidos de amido.

Tomamos amostras de fôlhas aproximadamente a $15 \mathrm{~cm}$ da extremidade da fôlha, já madura, de cada uma de 3 plantas, em intervalos de 2 horas, começando às 6,30 da manhã (Fastern War Time, nos Estados Unidos) do dia 27 de julho de 1943 até às 0,30 do dia 28 de julho, As 6,30 do dia 28, mais uma coleta foi feita de cada uma das 3 plantas. Cada amostra consistia de um pedaço de lâmina foliar de $2 \mathrm{~cm}$ de comprimento e $1.5 \mathrm{~cm}$ de largura. Apenas 2 amostras foram retiradas de cada fôlha, cada uma das amostras provindo de lados opostos da nervura principal c, $\mathrm{cm}$ todos os casos, foram coletados a intervalos sucessivos de tempo. As amostras foram retiradas apenas das fôlhas superiores da haste principal ou das principais perfilhações, onde as fôlhas se achavam bem expostas aos raios solares. As condições, provàvelmente, eram excelentes para a fotossintese, pois estava quente o dia $\mathrm{cm}$ que realizamos a coleta do material e havia adequada umidade no solo. As amostras de fôlhas foram fixadas no fixador de Craf. Algumas lâminas foram coloridas com a hematoxilina e outras com uma solução fraca de I-KI. Os testes preliminares haviam já indicado que os plastídios do invólucro do feixe vascular pareciam desprovidos de amido quando as amostras de fôlhas eram tiradas pela manhã, enquanto abundante quantidade de amido era constatada em horas mais avançadas do dia. As amostras de fôlhas coletadas às 6,30 da manhã de 27 de julho apresentavam os plastídios do invólucro do feixe vascular com pouco ou mesmo nenhum amido. Apenas, ocasionalmente, em algumas dessas células, podia ser constatado o amido pelo uso do I-KI. As amostras colhidas às 8,30 da manhã estavam completamente desprovidas de amido ; todo 0 amido presente nestes plastídios havia sido hidrolizado e translocado. Fncontramos grãos de amido nas amostras colhidas às 10,30 da manhã, mas cm uma quantidade relativamente pequena, como foi indicado pela intensidade de sua côr azul com o I-KI. As amostras colhidas às 12,30 mostravam uma quantidade notàvelmente maior de amido. Grãos de amido bem cheios se salientavam da superfície dos plastídios do invólucro e davam uma intensa coloração com o I-KI. As 3 amostras colhidas às 14,30 deram uma coloração mais fraca com o I-KI, indicando a presença de menor quantidade de amido do que às 12,30. Esta observação é importante, à vista do fato de que a manhã do dia 27 de julho se apresentava clara e ensolarada. Aproximadamente, porém, das 13 às 15 horas, o céu se tornou densamente nublado, diminuindo consideràvelmente a intensidade da luz. Pro- 
vàvelmente, ocorreu monor atividade fotossintética nas células do mesófilo durante o período nublado, menor quantidade de açúcar passou para o interior das células do invólucro do feixe vascular do que a quantidade transferida para o interior dos tecidos vasculares, de tal modo que parte clo amido acumulado pelos plastídios do invólucro nas últimas horas da manhã foi hidrolizado $\mathrm{em}$ açúcares solúveis e então translocado.

O céu se tornou novamente claro às 15 horas e o resto do dia permaneceu cnsolarado e claro. As amostras colhidas às 16,30 continham uma grande quantidade de amido, bem como as amostras colhidas àr 18,30 , 20,30 e 22,30 . A nossa impressão é de que a maior quantidade de amido ocorrell nas amostras colhidas às 18,30 ? 20,30, mas não fizemos nenhuma detcrminação quantitativa a êsse respeito.

() sol se pôs às 20,18 , no dia 27 de julho. Havia ainda uma considrrável quantidade de amido nos plastídios do invólucro dos feixes vasculares nas amostras coletadas às 0,30 do dia seguinte, porém menos do clue na amostra das 22,30 da noite anterior. Foi possível encontrar alguns plastídios rom uma fraca coloração azul nas amostras colhidas às 6,30 do dia 28 de julho, porém a maioria dos plastídios do invólucro parenquimatoso dos feixes não deram nenhuma indicação de amido com I-KI. Todo ou quase todo o amido formado nestes plastídios nas horas de sol do dia $2 i$ de julho tinha sido de novo transformado em açúcar durante a noite.

() sol surgiu às 5,46, no dia 27 de julho. Como já dissemos, era uma manhã quente e ensolarada. Uma quantidade mínima, porém visível, de amido, pôde ser encontrada em alguns plastídios do invólucro do feixe cm amostras das 6,30, enquanto nenhum amido foi constatado nas amostras das 8,30. Isto sugere que a hidrólise do amido armazenado não sé tinhat completado bem às 6,30 , mas se completou às 8,30 . Não seria fora de propósito supor que alguma atividade fotossintética tivesse ocorrido antes das 8,30. Provàvelmente, a velocidade fotossintética nesta ocasião cra tão baixa, que a velocidade com a qual o açúcar se locomoveu para dentro das células do invólucro foi menor do que a velocidacle da sua passagem das rélulas do invólucro para dentro dos elementos vasculares. Consequentrmente, não houve deposição de amido c a hidrólise e a translocação do amido formado no dia anterior se completou. Nas horas mais avauçadas do dia. maior quantidade de açúcar é sintetizada do que a que pode ser translocada pelos feixes vasculares e êste excesso de açúcar é, temporàriamente, armazenado na forma de amido nos plastídios do invólucro dos feixes vasculares. Wais tarde, quando cessa ou diminui a fotossíntese, êste amido é hidrolizado. - translocado para dentro dos foixes. Fsta interpretação é coerente com todos os fatcs observados c oferece uma explicação lógica para a presença dos plastídios especializados no invólucro do feixe vascular.

\section{OBSERVAÇŌES EM OUTRAS GRAMÎTEAS}

O milho pertence à sub-família Panicoideæ que inclui as tribos Andropogoneæ, Maydeæ e Panicex. Schwendener (10) achou que a maioria das espécies da sub-família Panicoideæ apresenta um invólucro parenquima- 
toso, mas não apresenta o mostoma envolvendo o feixe vascular. O sorgo é um membro da tribo Andropogonex. Um estudo das suas fôlhas revelou uma situaçâo semelhante à do milho. As células do invólucro parenquimatoso posiuem cloroplastos muito grandes, verde-claros, contendo muitos grãos de amido. A ocorrência de um ciclo diumo de depósito e remoção de amido provarelmente existe nestes plastíctios, tal como no milho, porém isto não foi estabelerido.

()s outros cereais mais comuns, como a aveia, o trigo e o centeio, pertencem ì sal-família Pooidede. Efotuamos apents um exame superficial da histologia de slaw follas. Nosios estudos foram realizados apenas em seçós de fôlhas novas fixarlas que haviam sido roletadas à tarde. Possivolmente, condiçoes diferentes seriam achadas $\mathrm{em}$ lôlhas mais velhas, desde que Percival (7) estabeleceu que o invólucro externo do feixe vascular das fôlhas mais volhas do trigo não contém on contém poucos plastídios. Nestes cereais, rada feixe vascular da folla é circundado por uma camada interna e outra ramada externa de célulat. Is células do invóhuero parencuimatoso aprescutam numerosos plastídios que, entretanto, são menores do que os plastídios do mesófilo. O mestona não tem plastídios. Apenas pequenas quantidados de smido, aparentemente dispostas em uma região central do plastídio, foram achadas no plastídio do invólucro parenquimatoso e também uos plastílios do mexófilo. Os plastídios do invóluero parenquimatoso c do mesófilo do trigo, da avera e do centeio apresentam tão pouco amido que slak fôlhas deram apenas uma leve coloração com I-KI. Contràriamente, a grande quantidade de amido achada nos plastídios do invólucro parencumatoso do milho e do sorgo dá a suas fôlhas uma côr preta intensa com I-KI. (Js plastídios do invólucro parenquimatoso foram achados concentrados no lado da célula voltado para o mesófilo. As observaçóes acima se aphioam para on trề gêneros, porém pequenas diferenças foram notadas. il maior diferença de tamanho entre os plastídlios do invóluero c os plastílios do mesófilo foi montrarla na fôlha do enteio, embora. uma diferença $\mathrm{om}$ tamanho exista tanto no trigo como na aveia (Fig. 7 ). Tanto cm estrutura como cm funçâo, os plastídios do invóhucro parenquimateso do trigo, da aveia a do centeio, todos membros da sub-fanília Pooidex, são decididamente diferentes dos plastídios do invóluero dos feixes vasculares do milho a do sorgo, que pertencem ì sub-lamília Panicoidex. Será intrresante verificar até onde diferem, nesta questão, os membros dosian duas sub-familias de gramineas.

\section{RES L MO}

As rélulas do mólucro parenquimatoso que envolve os feixes vas(ulares da fôtha do milho encerram plastídios especializados, de côr verde e relacienados rom a elaboração do amido. Os grãos de amido são formados no plastídio, em regiôses definidas e semelhantes a vacúolos. Um plastídio pode apresontar até 40 grãos de anido. O amido é depositado nestes plastídios apenas quando a velocidade da transferência do açúcar das células do mesófilo para o interior das células do invólucro do feixe vascular é maior 
do que a velocidade com a qual o açúcar passa das células do invólucro para os elementos vasculares. Os plastídios do invólucro do feixe vascular depositam amido em quantidades crescentes durante o dia. $\bar{A}$ noite, êsse amido é hidrolizado em carbohidratos solúveis e translocado, de modo que os plastídios ficam livres de amido pela manhã. Não encontramos nenhum amido nos plastídios do mesófilo nem de dia nem de noite. Os plastídios do invólucro do feixe vascular do sorgo são semelhantes em função aos do milho; esta especialização dos plastídios do invólucro do feixe vascular pode ser típica da sub-família Panicoidex. Os plastídios do invólucro parenquimatoso do trigo, da aveia e do centeio, todos membros da sub-família Pooideæx, são diferentes no tamanho e na função, comparados com os plastídios do milho e os do sorgo.

\section{SUMMARY}

The parenchyma sheath cells enclosing the vascular bundles of the corn leaf contain specialized plastids, green in color, concerned with the elaboration of starch. The starch grains are formed in definite vacuole-like regions in the plastıd. A plastid may have as many as 40 starch grains. Starch is deposited in these plastids only when the rate of movement of sugar from the mesophyll cells into the bundle sheath cells is greater than the rate with which sugar passes from the sheath cells into the vascular elements. The bundle sheath plastids deposit starch increasingly during the day. At night this starch is hydrolyzed to soluble carbohydrates and translocated so that the plastids are free of starch by morning. No starch was found in the mesophyll plastids at any time during the day or night. The bundle sheath plastids of sorghum are similar in function to those of maize : this specialization of the bundle sheath plastids may be typical of the subfamily Panicoideae. The parenchyma sheath plastids of wheat, oats, and barley, all members of the subfamily Pooidene, are different in size and function from those of maize and sorghum.

\section{LITERATURA CITADA}

1. Arber, Agnes. Em The Graminea. A study of cereal, bamboo, and grass. 1-480. 1934.

2. Avery, G. Comparative anatomy and morphology of embryos and seedlings of maize, oats, and wheat. Jot. Gaz. $39: 1-39.1930$.

3. Eames, A. J. \& L. H. MacDaniels. Em An introduction to plant anatomy. 1-364. 1925.

4. Esau, Katherine. Ontogeny of the vascular bundle in Zea mays. Hilgardia 15: 327-368. 1943.

5. Haberlandt, G. Em Physiological plant anatomy. 1-777. 1914.

6. Kiesselbach, T. A. Transpiration as a factor in crop production. Nebr. Exp. Sta. Res. Bull. 6: 1-214. 1916.

7. Percival, J. Em The wheat plant. A monograph. 1-453. 1921.

8. Rhoades, M. M. Genic induction of an inherited cytoplasmic character. Proc. Nat. Acad. 29 : 327-329. 1943.

9. Sayre, J. D. Physiology of stomata of Rumex patientia. Ohio Jour. Sei. 26 : 233-266. 1926.

10. Schwendener, S. Die Mestomscheiden der Gramineenblätter. Sitz.-ber. Akad. Berlin 1890 : 405-426. 1890.

11. Sharman, B. C. Developmental anatomy of the shoot of Zea mays I. Ann. Bot. 6 : 245-282. 1942. 
12. Spoehr, H. A., J. H. C. Smith, H. H. Strain, W. M. Manning, H. W. Milnere G. J. Hardin, Pigments of diatoms and algae. Carnegie: Inst. Wash. Yearb. 41 : 118-122. 1942.

13. Strasburger, E. Ueber den Bau and die Verrichtungen der Jeitungsbahnen in den Pflanzen. Histol. Beitr. 3 : 1-1000. 1891.

14. Weatherwax, P. Em Story of the maize plant. 1 247. 1923.

15. Weier, E. A comparison of the plastid with the Golgi zone. B1ol. Bull. 62 : $126-$ 139. 1932.

16. Zirkle, C. The structure of the chloroplast in certain higher plants. Amer. Jour. Bot. 13: 301-341. 1926.

17. Zirkle, C. Development of normal and divergent plastid types in Zea mays. Bot. Gaz. 88 : 186-203. 1929. 


\section{EXPLICACÃ̃ DAS FIGURAS}

FIGURA 1 - Secção transversal em uma fôlha de milho mostrando o invólucro parenquimatoso com uma só camada de células envolvendo o feixe vascular e apresentando plastídios elipsoidais achatados, contendo amido. A maioria dêstes plastídios são orientados de tal modo, que uma secção transversal da fôlha os apresenta em vista lateral. Alguns, entretanto, aparecem de frente. As células do invólucro encerram muito mais plastídios do que os apresentados no desenho. Em algumas células, os plastídios estão fortemente comprimidos como se formassem uma pilha de moedas. Na vista lateral dos plastídios, os grãos de amido se assemelham a pequenos corpos elipsoidais e, quando vistos de frente, apresentam uma forma esférica.

FIGURA 2 - Secção mediana de um plastídio pequeno do invólucro parenquimatoso visto de lado e mostrando o arranjo dos grãos de amido. Êstes são embutidos no plastídio, mas são separados uns dos outros por camadas finas de substância do plastídio. Êste plastídio contém 20 gráos de amido. Dez estão em um plano focal, os restantes permanecem acima e abaixo. A região central do plastídio não é visível quando vista desta posição. Êste plastídio é um elipśbide muito menos achatado do que os plastidios indicados na fig. 1 .

FIGURA 3 - Sceção transversal de uma fôlha de milho coletada às 16,30 horas, mostrundo os plastídios das células do invólucro parenquimatoso cheios de gyãos de amido. Fixada no fixador de Craf e colorida com hematoxilina. X 480 .

FIGUR A 4 - Seção longitudinal de uma fôlha de milho colorida com solução de I-KI fraca. Os grãos de amido nos plastídios do invólucro estão intensamente coloridos. Os plastídios do mesófilo (acima e abaixo do invólucro parenquimatoso) não dão indicação de amido. Notar o amido nas células guardas à direita, em baixo (ligeiramente fora de foco). X 480 .

FIGURA a -- Secção longitudinal da fôlha de milho colorida con I-KI, seguida pela remoção parcial do icdo com álcoois mais concentrados. Os grãos de amido são claramente visíveis nos plastídios um tanto inchados. $X 480$.

FIGL RA 6 - Seç̃̃o longitudinal de uma fôlha de milho coletada às 6,30 da manhã. Fixada em Craf e colorida ccm a hematoxilina. Os plastídios do invólucro parenquimatoso estão desprovidos de amido. As células do mesófilo permanecem à direita. O bordo mais colorido, que parcialmente eircunda a região central mais levemente colorida, é bem visível em alguns plastídios. As regiões semelhantes a vacúolos dêsse bordo colorido mais intensamente e onde os grãos de amido serão formados, podem ser vistas como regiões levemente coloridas. X 480 .

FIGLiRA 7 - Seç̧̃o transversal de uma fôlha de centeio, mostrando as células do invólucro parenquimatoso com plastídios pequenos e concentrados de um lado da célula. Êstes plastídios tomam uma coloração mais escura com a hematoxilina do que os plastídios maiores das células do mesófilo. X 360 .

FIGLRA 8 - Seção longitudinal de uma fôlha de milho coletada às 6,30 da manhã. Colorida com a hematoxilina. Quando vistos de frente, os plastídios do invólucro se assemelham aos dictiosomas do aparelho de Golgi. Notar as regiões semelhantes a vacúolos nos bordos do plastídio mais intensamente coloridos. $\mathrm{X} 480$. 


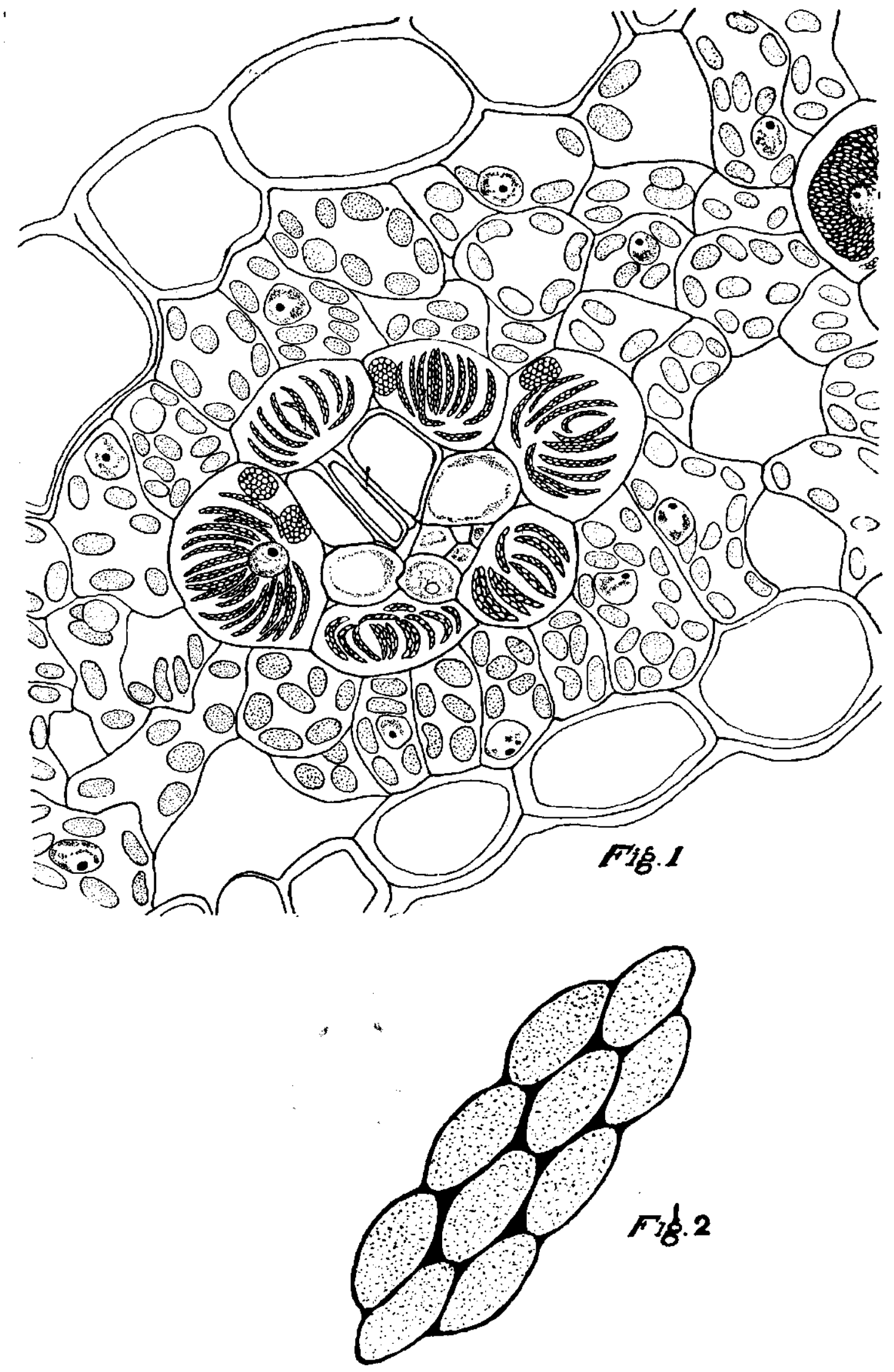




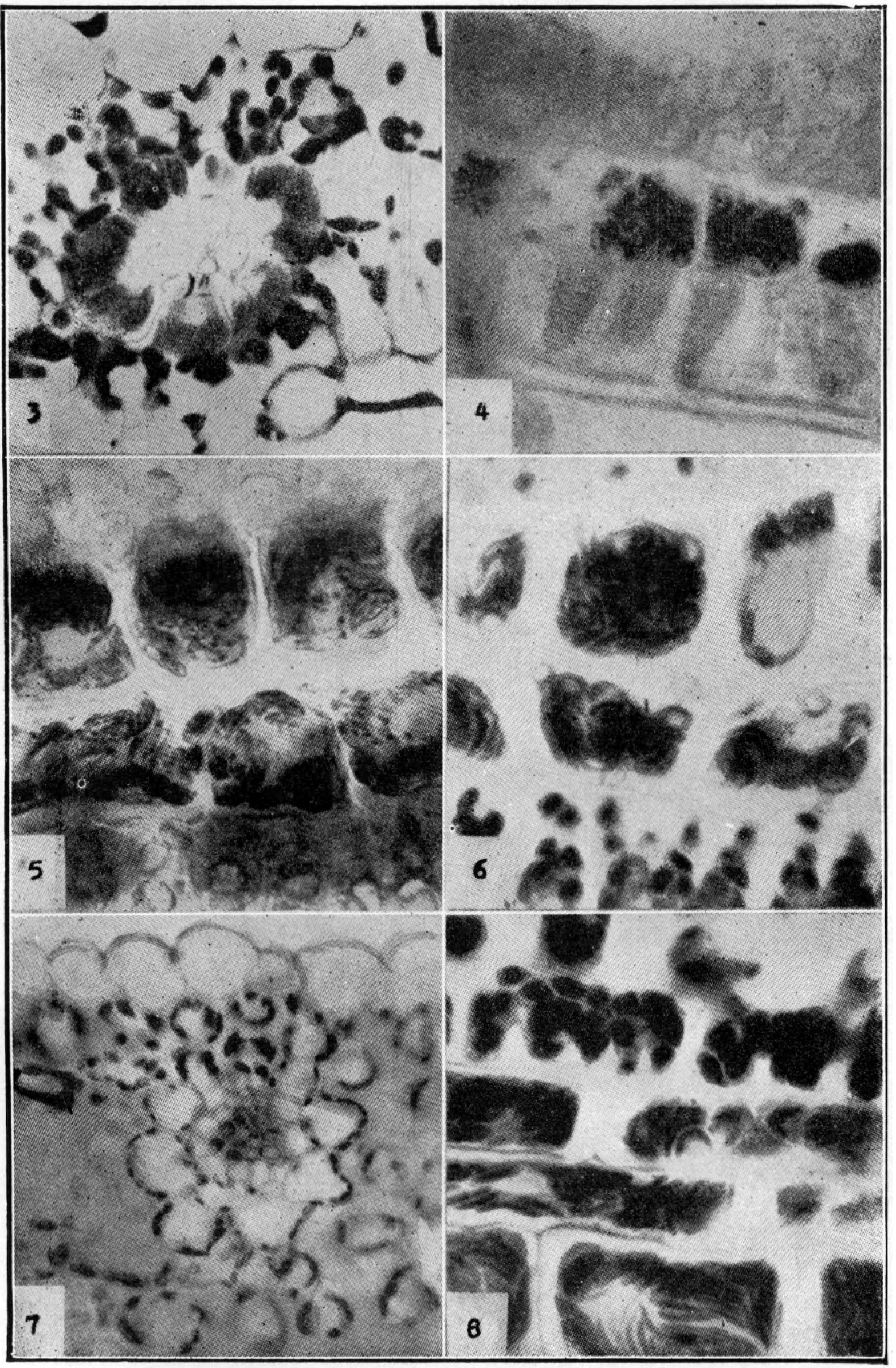

